Ann. Biol. anim. Bioch. Biophys., 1977, 17 (3 A), 331-340.

\title{
Effects of photoperiod and temperature on plasma gonadotropin and spermatogenesis in the rainbow trout Salmo gairdnerii Richardson
}

\author{
par B. BRETON, R. BILLARD \\ with the technical assistance of Pierrette REINAUD and Anne-Marie ESCAFFRE \\ Laboratoire de Physiologie des Poissons, I.N.R.A. \\ 78350 Jouy-en-Josas, France
}

Summary. Two-year old male rainbow trout, Salmo gairdnerii, were exposed to the following photoperiods at $8^{\circ}$ or $16^{\circ} \mathrm{C}$ from February 24 to June 19 : constant short photoperiod $(8 \mathrm{~L}+16 \mathrm{D})$, constant long photoperiod $(16 \mathrm{~L}+8 \mathrm{D})$, and gradually decreasing photoperiod (from $16 \mathrm{~L}$ to $8 \mathrm{~L}$ ). Control fish were exposed to natural photoperiod and temperature. Plasma and pituitary gonadotropin levels were determined by radioimmunoassay and correlated with spermatogenic response in testes. Control fish did not show advancement of spermatogenesis, whereas those exposed to decreasing photoperiod at $8^{\circ}$ or $16^{\circ} \mathrm{C}$ showed complete induction of spermatogenesis. While cooler temperature favoured production of spermatogonia and spermatocytes, the warmer temperature stimulated formation of spermatids and spermatozoa. On the other hand, in trout exposed to constant short or constant long photoperiod, spermatogenic response was weak at both temperatures. Plasma GtH levels increased in groups kept under decreasing photoperiod at both $8^{\circ} \mathrm{C}$ as well as $16^{\circ} \mathrm{C}$; the magnitude of rise of $\mathrm{GtH}$ was greater at $16^{\circ} \mathrm{C}$ than at $8^{\circ} \mathrm{C}$. GtH levels were significantly higher in trout exposed to gradually decreasing photoperiod than in animals kept under constant short or constant long photoperiod at $8^{\circ}$ or $16^{\circ} \mathrm{C}$. The data suggest that the optimum photothermal combination for $\mathrm{GtH}$ release and induction of spermatogenesis in the rainbow trout is a gradually decreasing photoperiod (from $16 \mathrm{~L}$ to $8 \mathrm{~L})$ at $16^{\circ} \mathrm{C}$.

\section{Introduction.}

Many investigators have shown that in teleost fishes gonadal recrudescence can be advanced by manipulations of photoperiod and temperature. De Vlaming (1972, 1974), Jalabert (1976) and Sundararaj and Vasal (1976) have recently reviewed the relevant literature. As far as salmonid fishes are concerned, Hoover and Hubbard (1937) achieved complete maturation in Salvelinus fontinalis 15 weeks before normal spawning, by reduction of the normal photoperiodic cycle at $7{ }^{\circ} \mathrm{C}$. Nomura (1962) obtained similar results in the rainbow trout but at $10^{\circ} \mathrm{C}$. Comparable results were also obtained by Hazard and Eddy (1951) and Henderson (1963) in Salvelinus fontinalis, 
Allison (1951) and Corson (1955) in the brown trout, Salmo trutta and Goriszko (1972) in rainbow trout, Salmo gairdnerii. In all these experiments, effects of photoperiod and temperature were evaluated by parameters of sexual maturation such as ovulation and spermiation. As yet, no data on the dynamics of spermatogenesis and hormonal variation are found in the literature.

In the experiment reported in the present paper, the effects of these two factors were investigated in the male rainbow trout by measuring the pituitary and plasma gonadotropin ( $\mathrm{t}-\mathrm{GHH})$ concentrations in correlation with quantitative analysis of spermatogenesis.

\section{Material and methods.}

Collection and care of fish and experimental installations.

Two-year old rainbow trout, weighing about $150 \mathrm{~g}$ were obtained from the Forgeot Fish Farm (Loiret, France). They were allocated into fourteen subgroups (duplicate) each containing 10 animals in 300-liter tanks. Two tanks were used for each of the experimental groups.

The first group, which served as the control, was maintained under natural photoperiod and temperature in a recirculating water system, in which the water was purified by passage under pressure through a bacterial filter (Petit, 1974).

Six other experimental groups were maintained in a similar but independent system, in which the water temperature was regulated to the nearest $0.1^{\circ} \mathrm{C}$ by means of an electronic regulator (Fayard, 1975). Two super white and one blue Philips fluorescent fubes were used for illumination in each environmental room, and the duration of photoperiod was regulated by a time-switch. Light intensity at the surface of the water was 1200 lux.

The six combinations of light-temperature used were : I. Constant temperature of $16^{\circ} \mathrm{C}$ and long photoperiod $(16 \mathrm{~L}+8 \mathrm{D})$, 11 . Constant temperature of $16^{\circ} \mathrm{C}$ and short photoperiod $(8 \mathrm{~L}+16 \mathrm{D})$, III. Constant temperature of $16^{\circ} \mathrm{C}$ and gradually decreasing photoperiod from $16 L+8 D$ on $17 / 02 / 74$ to $8 L+16 D$ on $21 / 06 / 75$. In this case, the duration of photoperiod was adjusted weekly to approximate the natural decrease in photoperiod from 21 June to 21 December (see fig. 1).

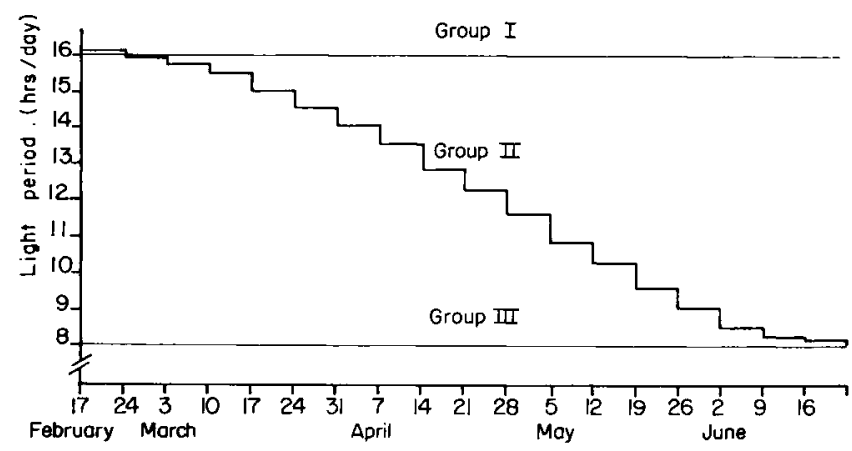

FIG. 1. - Time schedule of light in experimental groups. 
Groups of fish in IV, V and VI were held under the same photoperiod as in I, II and III respectively but at $8^{\circ} \mathrm{C}$.

Experimental procedure.

Thermal acclimation of rainbow trout began on February 1 under natural photoperiod and the experiment was commenced on 17 February.

From this date onwards blood was sampled every two weeks by heart puncture with a $1 \mathrm{ml}$ tuberculin disposable syringe (26/6 needle) from anesthetised fish (propoxate R 7464 Janssen pharmaceutica, $2 \mathrm{ppm}$ ). The blood was centrifuged for $10 \mathrm{mn}$ at $3000 \mathrm{rpm}$ at $4^{\circ} \mathrm{C}$. The plasma samples were stored at $-20^{\circ} \mathrm{C}$ until analysis.

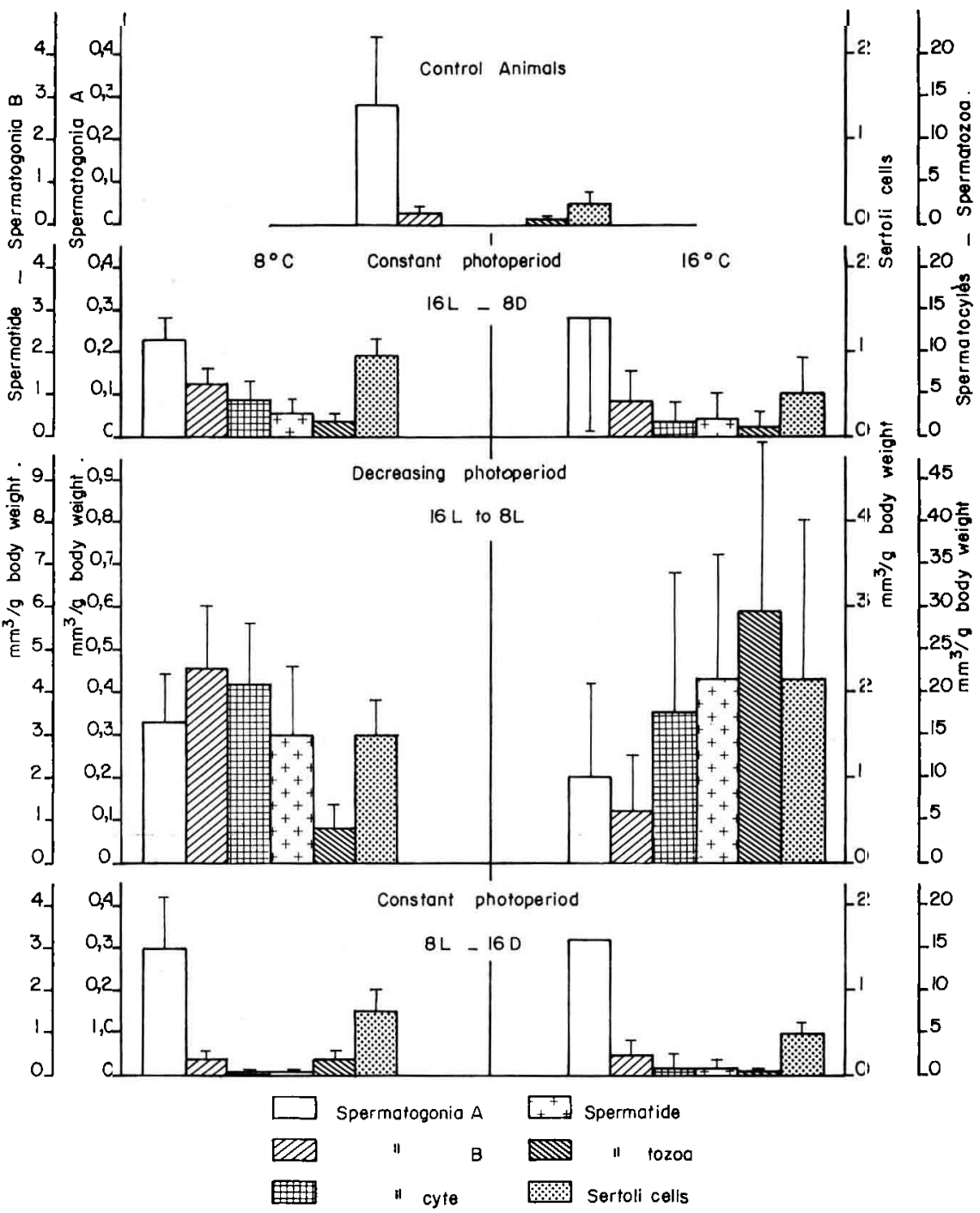

FIG. 2. - State of gametogenesis ot the end of the experiment (June 19th). 
The experiment was terminated on June 19. All the surviving animals were killed by decapitation after a last blood sampling. Body and testes weights were taken and the gonadosomatic index (GSI) determined. A part of the testis was fixed in BouinHollande and histologically analysed according to the technique of Billard ef al. (1974). Pituitaries were collected on ice immediately after decapitation, weighed to the nearest $0.1 \mathrm{mg}$ on a Mettler ME 22 balance, homogenized by 5 to 10 strokes in a glass teflon homogenizer in $0.05 \mathrm{M}$ veronal buffer $\mathrm{pH} 8.6$ containing $2.5 \mathrm{p} .100$ of human serum albumin ( $5 \mathrm{mg} / \mathrm{ml}$ concentration) and stored at $-20^{\circ} \mathrm{C}$.

Plasma and pituitary gonadotropin concentrations were determined by a radioimmunoassay (RIA). The double antibody RIA system for trout gonadotropin was carried out with the highly purified t-GHH (Breton ef al., 1976). The hormone was labelled by chloramine T method with $\mathrm{I}^{125}$ (Greenwood et al., 1963) under the same conditions used for the carp gonadotropin (Breton ef al., 1971). The antibody raised against the pure $\mathrm{t}-\mathrm{GtH}$ in guinea pig was used at a 1/200000 final concentration. The sensitivity of the assay was 7 to $10 \mathrm{pg}$.

Statistical analyses were done by using the F-test of Fisher and analysis of variance. The mean and standard deviation are given in graphs.

\section{Results.}

\section{Spermatogenesis.}

In the controls, the testis remained in the resting stage with type A spermatogonia, few cysts of type B spermatogonia with no other spermatogenic stages (fig. 2). The gonadosomatic index was very low (table 1).

TABLE 1

Mean gonadosomatic index (GSI) under the different light-temperature combinations

\begin{tabular}{ccccc}
\hline Control & & & \multicolumn{1}{c}{$\begin{array}{c}\text { decreasing } \\
\text { photoperiod } \\
16 \mathrm{~L} \rightarrow 8 \mathrm{~L}\end{array}$} & $8 \mathrm{~L}-16 \mathrm{D}$ \\
\hline \multirow{2}{*}{$0.28 \pm 0.16$} & $8^{\circ} \mathrm{C}$ & $0.41 \pm 0.38$ & $4.58 \pm 2.05$ & $0.46 \pm 0.33$ \\
\cline { 2 - 5 } & $166^{\circ} \mathrm{C}$ & $0.64 \pm 0.40$ & $9.02 \pm 2.31$ & $0.36 \pm 0.29$ \\
\hline
\end{tabular}

Mean \pm standard error (SE).

In the experimental groups, there was no difference between the duplicates and results of the two subgroups were pooled. The stages of advancement of spermatogenesis are summarized in figure 2.

Complete spermatogenesis occurred only in groups exposed to decreasing photoperiod at $8^{\circ}$ or $16^{\circ} \mathrm{C}$. The warmer temperature accelerated spermatogenesis; a greater number of spermatozoa was produced at $16^{\circ} \mathrm{C}(29.36 \pm 20.03)$ than at $8^{\circ} \mathrm{C}$ $(3.95 \pm 2.24)$ with a higher number of spermatogonia at the lower temperature than 
at $16^{\circ} \mathrm{C}(4.55 \pm 1.56$ against $1.21 \pm 1.29)$. These two groups of values are significantly different ( $p .<0.01)$.

In the groups kept under short or long photoperiod, spermatogenic response was very weak although it was stimulated under long photoperiod especially at $8{ }^{\circ} \mathrm{C}$. The number of type $B$ spermatogonia $(1.25 \pm 0.31)$ and spermatocytes $(4.13 \pm 2.31)$ was greater $(p<0.01)$ under long photoperiod than under the short one $(0.35 \pm 0.21$ and $0.24 \pm 0.16$ respectively), the production of spermatozoa was also higher under long photoperiod than under the short one $(p<0.05)$.

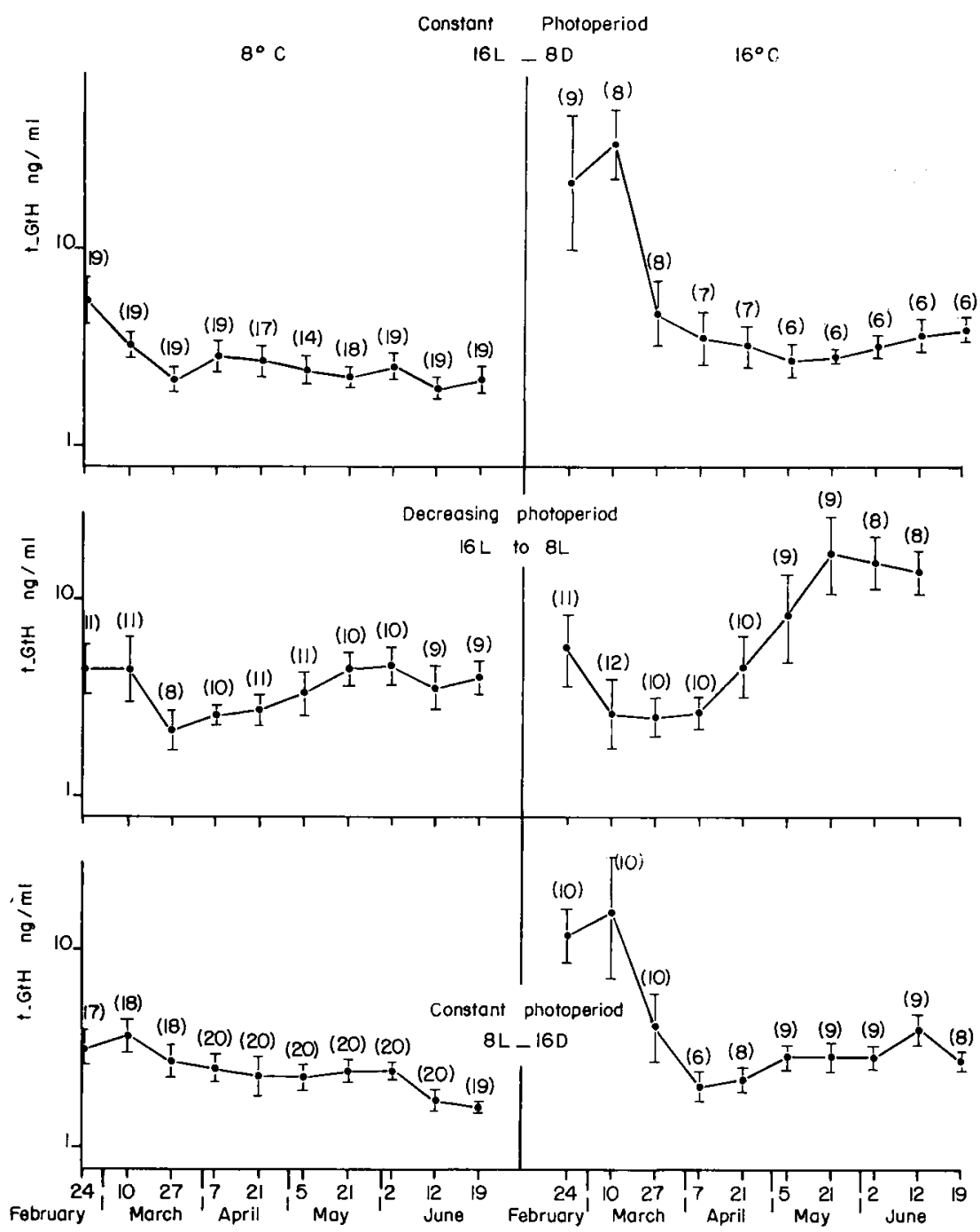

FIG. 3. - Variations in plasma immunoreactive t-GtH levels in experimental groups.

( ) give the number of values. 
Plasma gonadotropin levels.

Results were similar in the two duplicate subgroups, and were, therefore, pooled.

Variations in plasma content of immunoreactive $t-G+H$ are given in figure 3 for the experimental and in figure 4 for the control group kept under natural photoperiod.

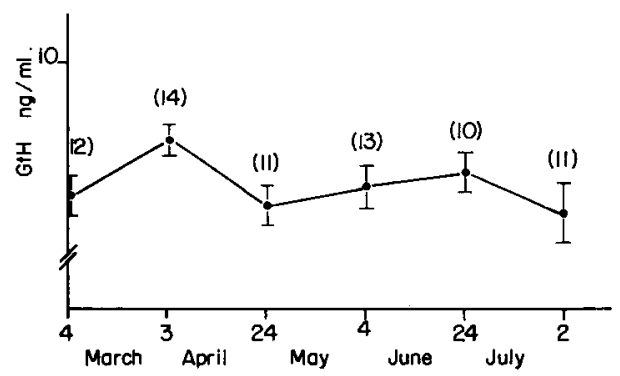

FIG. 4. - Variations in plasma immunoreactive $t-G t H$ levels in control animals.

( ) give the number of values.

a) Effects of photoperiod.

Plasma t-GtH levels increased between the beginning and the end of the experiment in the groups kept under decreasing photoperiod at both the temperatures used, and these values are significantly higher than in animals kept under constant long or constant short photoperiod either at $8^{\circ}$ or $16^{\circ} \mathrm{C}$ (fig. 3 and table 2) especially at the end of the experimental period after May 20. Thus in the groups subjected to decreasing daylength, reproducing the natural photoperiodic cycle, the natural profile of $\mathrm{GHH}$

TABLE 2

Statistical levels of significance between plasma gonadotropin concentrations under the different experimental photoperiods (date to dafe analysis)

NS : non significant; ${ }^{* *}: \mathrm{P}<0,001 ;{ }^{* *}: \mathrm{P}<0.01 ; *: \mathrm{P}<0.05$.

\begin{tabular}{|c|c|c|c|c|c|c|c|}
\hline \multirow{2}{*}{ Pair of groups } & \multirow{2}{*}{$\frac{\text { April }}{5}$} & \multicolumn{2}{|c|}{ May } & \multicolumn{3}{|c|}{ June } & \multirow{2}{*}{ Temperature } \\
\hline & & 5 & 20 & 2 & 12 & 19 & \\
\hline $\begin{array}{l}16 L-8 D \\
16 L-8 L\end{array}$ & NS & NS & $* * *$ & NS & $* *$ & $* *$ & \\
\hline $\begin{array}{r}16 L-8 L \\
8 L-16 D\end{array}$ & NS & NS & $* * *$ & $* * *$ & $* * *$ & $* * *$ & $8^{\circ} \mathrm{C}$ \\
\hline $\begin{array}{r}16 L-8 D \\
8 L-16 D\end{array}$ & NS & NS & NS & NS & NS & NS & \\
\hline $\begin{array}{l}16 L-8 D \\
16 L-8 L\end{array}$ & NS & NS & $*$ & $* * *$ & $* * *$ & $*$ & \\
\hline $\begin{array}{r}16 L-8 L \\
8 L-16 D\end{array}$ & NS & NS & $*$ & $* * *$ & $* * *$ & $* * *$ & $16^{\circ} \mathrm{C}$ \\
\hline $\begin{array}{r}16 L-8 D \\
8 L-16 D\end{array}$ & NS & NS & NS & NS & NS & $*$ & \\
\hline
\end{tabular}


secretion from July to spermiation time was found. In contrast, under constant short or constant long photoperiod, the gonadotropin level decreased over the same period. There was no significant difference between trout kept under constant long or short photoperiod and the controls.

b) Effects of temperature.

Regardless of photoperiodic regime, $t-G+H$ levels were significantly higher at $16^{\circ} \mathrm{C}$ than at $8^{\circ} \mathrm{C}$ ( $\mathrm{p}<0.001, \mathrm{~F}$ test) for each date. Similarly the overall mean $\mathrm{GtH}$ concentration throughout the experiment was higher at $16^{\circ} \mathrm{C}$ than at $8^{\circ} \mathrm{C}$ (table 3 ).

TABLE 3

Mean plasmatic GtH values throughout the experimental period $(\mathrm{ng} / \mathrm{ml})$

\begin{tabular}{|c|c|}
\hline Photoperiod & $16^{\circ} \mathrm{C}{ }^{\mathrm{GtH}}(\mathrm{ng} / \mathrm{ml})$ \\
\hline $16 L-8 D \ldots \ldots$ & $6.91 \underset{(69)}{ \pm} 0.59 * * * 4.32 \pm 0.39$ \\
\hline $16 \mathrm{~L} \rightarrow 8 \mathrm{~L} \ldots \ldots$ & $\underset{(88)}{8.83 \pm 0.78 * * * 6.18 \pm \underset{(100)}{ \pm} 0.31}$ \\
\hline $8 L-16 D \ldots \ldots$ & $\begin{array}{c}5.41 \underset{(88)}{ \pm} 0.32 * * 4.27 \pm 0.19 \\
(189)\end{array}$ \\
\hline $\begin{array}{l}* * *: P<0.001 . \\
* *: P<0.01 \\
(): \text { Number } 0 \\
\text { Mean values } \pm\end{array}$ & ves. \\
\hline
\end{tabular}

Pituitary gonadotropin levels.

No significant difference was found either in temperature or in photoperiodtreated animals. However, statistical analysis is not possible because of the heterogeneity of results (table 4). The only significant result is obtained at $16^{\circ} \mathrm{C}$ between animals kept under decreasing photoperiod and constant short photoperiod $(p<0.05)$.

TABLE 4

Pituitary gonadotropin contents in the rainbow frout, under the different photoperiod temperature combinations. Results are expressed in $\mathrm{ng} \mathrm{GtH} / \mathrm{mg}$ of fresh pifuitary gland

\begin{tabular}{cccc}
\hline & \multicolumn{3}{c}{ Photoperiod } \\
\cline { 2 - 4 } Temperature & $16 \mathrm{~L}-8 \mathrm{D}$ & $\begin{array}{c}\text { decreasing } \\
\text { photoperiod } \\
16 \mathrm{~L} \rightarrow 8 \mathrm{~L}\end{array}$ & $8 \mathrm{~L}-16 \mathrm{D}$ \\
\hline $8^{\circ} \mathrm{C}$ & $522 \pm 51.2(12)$ & $880.4 \pm 84(7)$ & $666.8 \pm 72.5(16)$ \\
\hline $16^{\circ} \mathrm{C}$ & $386.4 \pm 38.6(6)$ & $605 \pm 82.3(8)$ & $165.6 \pm 12.5(8)$
\end{tabular}

Mean values \pm standard deviation (SD). 


\section{Discussion.}

We have limited information concerning plasma gonadotropin levels in salmonid species. Except our earlier results (Breton et al., 1976) the only other published information is that of Crim et al. $(1973,1975)$, wherein they have reported significantly higher gonadotropin levels in spermiating land-locked salmon and brook trout. They, however, did not relate $\mathrm{GtH}$ levels with the entire annual reproductive cycle of the fish, but only with the last stages of sexual maturation. In the brook trout plasma GHH was not defectable during the resting period of the testes, but increased steadily from August to October as spermatogenesis advanced (Crim et al., 1975). The results obtained in this study under decreasing photoperiod, regardless of temperature, are quite similar and are comparable with the natural profile of $\mathrm{GHH}$ secretion in the rainbow trout from the beginning of the spermatogenesis (August) up to spermiation (November-December) (Breton et al., 1975). Comparison with values given by Crim ef al. (1975) is difficult since they did not mention the range of temperature.

The effect of temperature on $\mathrm{GtH}$ secretion seems to be very important and acts by amplification of the mean values of gonadotropin concentration, regardless of photoperiod. Under decreasing photoperiod, the magnitude of gonadotropin rise is greater at $16^{\circ} \mathrm{C}$ than at $8^{\circ} \mathrm{C}$. Thus at $8^{\circ} \mathrm{C}$ the increase of $\mathrm{GtH}$ concentration began with $4.72 \pm 0,37 \mathrm{ng} / \mathrm{ml}$ in early April and reached $6.88 \pm 0,79 \mathrm{ng} / \mathrm{ml}$ in late June, whereas at $16^{\circ} \mathrm{C} \mathrm{GtH}$ level increased from $4.48 \pm 1.04$ to $11.23 \pm 1.11 \mathrm{ng} / \mathrm{ml}$ during the same period.

In the consiant photoperiod groups the profile of gonadotropin secretion is like the natural profile with a slight decrease, or a maintenance at a low level from January (after spermiation) to July. This diminution, especially during the month after acclimation is more pronounced at $16^{\circ} \mathrm{C}$ than at $8^{\circ} \mathrm{C}$. This is similar to the situation noticed in the goldfish (Gillet ef al., 1976) where acclimation to high temperature $\left(\geqslant 17{ }^{\circ} \mathrm{C}\right.$ ) induced a rise in $\mathrm{GHH}$ level. This differential response could be attributed to the respective photoperiodic regimes. Goldfish were kept under an increasing photoperiod, whereas trout were under constant short or constant long photoperiod, and decreasing photoperiod.

The results of the present study show that under constant short or long photoperiod spermatogenesis including formation of spermatozoa is qualitatively but not quantitatively induced. Only a decreasing photoperiod is able to induce complete spermatogenesis, mediated through a rise in gonadotropin secretion. Henderson (1968), and Combs ef al. (1959) already postulated that decreasing photoperiod is necessary to induce spermatogenesis in the brook trout. On the other hand, Backiel (1964) suggested that warm temperature stimulated the last stage of spermatogenesis. The difference in the plasma gonadotropin levels at $8^{\circ} \mathrm{C}$ and $16^{\circ} \mathrm{C}$ could explain the effect of temperature on spermatogenesis.

It has been suggested that the development of the different phases of spermatogenesis may have different temperature thresholds. In the present study in trout under decreasing photoperiodic regime, spermatogonial divisions and primary spermatocyte formation may be influenced by low temperatures, while spermatozoa production is possibly enhanced by warm temperatures. Similar observations were made 
by Ashan (1968) in Couesius plumbeus, who found that high temperatures accelerate spermatogonial proliferation and hasten spermiation, but low temperatures are necessary for the formation of primary spermatocytes (see also Harrington, 1959). On the contrary, Lofts ef al. (1968) postulated that in Fundulus heteroclitus, an elevation of temperature accelerates the spermatogonial activity.

In rainbow trout it appears that initiation of spermatogenesis can occur under long photoperiod, it can be advanced under a long or decreasing photoperiod at warm temperature, while spermiation takes place under short daylengths at low temperature.

In trout, the qualitative induction of total spermatogenesis does not seem to require very high levels of GtH, which is different from the goldfish (Gillet, 1975) where quantitatively restcred spermatogenesis needs higher plasma gonadotropin concentration.

The present study has demonstrated that in the rainbow trout it is possible to obtain fully mature males, six months after the natural spawning period. It does not throw light on the existence of a refractory period, as demonstrated in other species such as Notropis bifrenatus (Harrington, 1957) and Fundulus confluentus (Harrington, 1959). It may exist, if at all, between 21 December and 24 February which is prior to the initiation of our experiment. We shall try to resolve this problem in future experiments.

Accepté en décembre 1976.

Acknowledgments. - This work was supported by Electricité de France (EDF) (Grant no 8375) and European Economic Communoty (Grant no 045.74.1.ENV).

Résumé. Les effets de la température et de la photopériode sur le cycle reproducteur de la truite Arc-en-ciel mâle sont appréciés par l'analyse quantitative de la spermatogenèse ef la dynamique de sécrétion d'hormone gonadotrope (G+H) mesurée par radioimmunologie.

Seule une photopériode décroissante de 16 à $8 \mathrm{~h}$ de lumière par jour, appliquée dès le mois de février en fin de période de spermiation naturelle est susceptible d'induire un nouveau cycle spermatogénétique dans les 4 mois qui suivent. Dans ces conditions, une élévation de la température stimule la spermatogenèse qui esł complète (formation de spermatozoïdes) à $16^{\circ} \mathrm{C}$. Sous photopériode constante longue ou courte, l'activité spermatogénétique est faible, une légère stimulation des divisions spermatogoniales et une augmentation du nombre de spermatocytes sont enregistrées sous photopériode constante $16 \mathrm{~L}-$ $8 \mathrm{~N}$, spécialement à $8{ }^{\circ} \mathrm{C}$. Quel que soit le rythme phofopériodique, le taux d'hormone gonadotrope circulante est plus élevé à $16^{\circ} \mathrm{C}$ qu'à $8^{\circ} \mathrm{C}$. Sous photopériodes constantes longues et courtes, les niveaux gonadotropes décroissent du début à la fin de l'expérience, alors qu'ils s'élèvent en fin d'expérience sous photopériode décroissante. Cette élévation est plus marquée à 16 qu'à $8^{\circ} \mathrm{C}$.

La photopériode apparaît être le facteur qui induit l'augmentation de la sécrétion gonadotrope et la phase de gamétogenèse active, la température ayant un rôle facilitant.

\section{References}

AHSAN S. N., 1965. Effects of temperature and light on the cyclical changes in the spermatogenetic activity of the lake chub, Couesius plumbeus (Agassiz). Con. J. Zool., 44, 161-171.

ALLISON L. N., 1951. Delay of spawning in eastern brook trout by means of artificially prolonged light intervals. Prog. Fish. Cult., 13, 111-116.

BACKIEL T., 1964. Pstragi. PWRiL, Warszawa, 49-62.

BILLARD R., SOLARI A., ESCAFFRE A. M., 1974. Méthode d'analyse quantitative de la spermatogenèse des poissons téléostéens. Ann. Biol. anim. Bioch. Biophys., 14, 87-104. 
BRETON B., KANN G., BURZAWA-GERARD E., BILLARD R., 1971. Dosage radioimmunologique d'une hormone gonadotrope de Carpe (Cyprinus carpio L.). C. R. Acad. Sei., Paris, Série D, 272, 1515-1517.

BRETON B., JALABERT B., REINAUD P., 1976. Purification of gonadotropin from rainbow trout (Salmo gairdnerii Richardson) pituitary glands. Ann. Biol. anim. Bioch. Biophys., 16, 25-36.

BRETON B., JALABERT B., FOSTIER A., BILLARD R., 1975. Etude sur le cycle reproducteur de la truite Arc-en-Ciel et de la tanche. J. Physiol., 70, 561-564.

COMBS B. D., BURROWS R. E., BIGEJ R. G., 1959. The effect of controlled light on the maturation of adult Blueback Salmon. Progr. Fish. Cult., 21, 63-69.

CORSON B. W., 1955. Four years progress in the use of artificially controlled light to induce early spawning of brook trout. Progr. Fish. Cult., 21, 63-69.

CRIM L. W., MEYER R. K., DONALDSON E. M., 1973. Radioimmunoassay estimates of plasma gonadotropin levels in the spawning pink salmon. Gen. comp. Endocrinol, 21, 69-76.

CRIM L. W., WATTS E. G., EVANS D. M., 1975. The plasma gonadotropin profile during sexual maturation in a variety of salmonid fishes. Gen. comp. Endocrinol., 27, 62-70.

DE VLAMING V., 1972. Environmental control of teleost reproductive cycles : a brief review. J. Fish. Biol., 4, 131-140.

FAYART G., 1975. Etude d'un système de contrôle et de régulation hydraulique et thermique applicable à la recherche hydrobiologique. Notice technique CEA-NT-50, $32 \mathrm{p}$.

GILLET C., 1975. Etude des effets de la température sur le cycle reproducteur du cyprin Carassius auratus. D. E. A., Univ. Paris VI, 26 p.

GILLET C., BILLARD R., BRETON B., 1977. Effets de la fempérature sur la sécrétion gonadotrope hypophysaire et la gaméłogenèse du poisson rouge Carassius auratus. Can. J. Zool., 55, 242-245.

GORYCZKO K., 1972. A change of the spawning season in rainbow trout (Salmo gairdnerii Richardson). Rocz. Nauk. roln., 94H, 57-68.

GREENWOOD F., HUNTER W., GLOVER J., 1963. The preparation of $\left.\right|^{131}$ labeled human growth hormone of high specific radioactivity. Biochem. J., 89, 114-123.

HARRINGTON J., 1959. Effects of four combinations of temperature and daylength on the ovogenetic cycle of a low latitude fish Fundulus confluentus goode and bean. Zoologica N. Y., 44, 149-168.

HARRINGTON R. W., 1957. Sexual pholoperiodicity of the cyprinid fish, Notropis bifrenatus in relation to the phase of its annual reproductive cycle. J. exp. Zool., 135, 529-553.

HAZAR T. P., EDDY R. E., 1951. Modification of the sexual cycle in brook trout Salvelinus fontinalis by control of light. Trans. Amer. Fish. Soc., 80, 158-162.

HENDERSON N. E., 1963. Influence of light and temperature on the reproductive cycle of the eastern brook trout, Salvelinus fontinalis Mitchill. J. Fish. Res. Bd. Can., 20, 859-897.

HOOVER E. E., HUBBARD H. E., 1937. Modification of the sexual cycle in trout by control of light. Copeia, 4, 206-211.

JALABERT B., 1979. Contrôle de la reproduction par les facteurs externes chez les poissons. Océanis, 2, $141-150$.

LOFTS B., PICKFORD G. E., ATZ J. W., 1968. The effect of low temperature, and cortisol, on testicular regression in the hypophysectomized cyprinodont fish, Fundulus heteroclitus. Biol. Bull., 134, 74-86.

NOMURA M., 1962. Studies on reproduction of rainbow trout Salmo gairdnerii with special reference to egg taking. III. Acceleration of spawning by control of light. Bull. jap. Soc. Sci. Fish., 28, 1070-1076.

PETIT J., 1974. Recyclage ef épuration en pisciculture : étude théorique et bibliographique. Coll. Aquacult. CNEXO, Brest Octobre 1973, 445-470.

SUNDARARAJ B. I., VASAL S., 1976. Photoperiod and temperature control in the regulation of reproduction in the female catfish Heteropneustes fossilis. J. Fish. Res. Bd. Can., 33, 959-973. 